Relations industrielles

Industrial Relations

\title{
Technology Puts Out the Firemen
}

\section{Émile Gosselin}

Volume 13, numéro 3, juillet 1958

URI : https://id.erudit.org/iderudit/1022427ar

DOI : https://doi.org/10.7202/1022427ar

Aller au sommaire du numéro

Éditeur(s)

Département des relations industrielles de l’Université Laval

ISSN

0034-379X (imprimé)

1703-8138 (numérique)

Découvrir la revue

Citer ce document

Gosselin, É. (1958). Technology Puts Out the Firemen. Relations industrielles / Industrial Relations, 13(3), 333-336. https://doi.org/10.7202/1022427ar
Résumé de l'article

The following text analyzes the dispute which culminated in a strike involving the Brotherhood of Locomotive Firemen and Enginemen and the Canadian Pacific Railway. It deals with the complex problems of technological change in a continent-wide economic setting, and suggests structural modifications of the unions concerned in order to adequately cope with them.
Tous droits réservés @ Département des relations industrielles de l’Université Laval, 1958
Ce document est protégé par la loi sur le droit d'auteur. L’utilisation des services d'Érudit (y compris la reproduction) est assujettie à sa politique d'utilisation que vous pouvez consulter en ligne.

https://apropos.erudit.org/fr/usagers/politique-dutilisation/ 


\title{
Technology Puts Out the Firemen
}

\author{
Emile Gosselin
}

\begin{abstract}
The following text analyzes the dispute which culminated in a strike involving the Brotherhood of Locomotive Firemen and Enginemen and the Canadian Pacific Railway. It deals with the complex problems of technological change in a continent-wide economic setting, and suggests structural modifications of the unions concerned in order to adequately cope with them.
\end{abstract}

On Tuesday evening, May 13, 1958, a Canadian though truly regional strike came to a foregone conclusion. The rich strike fund of the Brotherhood of Locomotive Firemen and Enginemen bowed and gave the first round to the railroad employers of North America. It was not a knockout, not even a slip on the floor. The recent events and the discussions between the Brotherhood and the Canadian National Railways appear to be mere shadow boxing and muscle flexing before the real exchange of blows between two extremely powerful giants in the field of economics and labor relations: railway companies and railway Unions of North America.

For more than two decades the relationship between both sides have presented us with a most amazing and unusual case in the field of courtships. Not only there developed strongly reinforced labor and management traditions, but again both sides went about building piece by piece a seemingly unpregnable fortress of rules, practices, covenants, regulations and understandings. The fraternal temple had high walls but contained many mansions. Under a solid roof of security, employers, unions and members alike enjoyed the good old life and it appeared that the old order could be perpetuaded forever and ever. It was as if the Victorian age were still among us. To the distress of all the occupants, competition is ruining the foundations of the house while technology is blowing the roof away.

The recent industrial disputes in the Canadian railways present a few characteristics: 1) They surge mostly from recent advances in the field of automation; 2) They are primarily not Canadian disputes by their origin, their nature and their effects; 3) They constitute an episode of a family brawl whose participants live for the most part outside Canada; 4) They are real indices of the end of an era in the field of craft and multi-craft unionism. If such caracteristics describe the real underlying issues of the dispute, we may perhaps discuss in a better light the recent interventions of the Canadian Government and indicate more clearly the road which has to be cut in the future by railroad unions throughout North America. 
The Brotherhood of Locomotive Firemen and Enginemen had 10,603 members in Canada in 1957, some 3,000 of them being employed by the Canadian Pacific Railway as firemen. But the union is an international body bargaining collectively for its members with more than 140 railway companies in the USA and Canada. A note must be made here to the effect that the Canadian Pacific and the Canadian National Railways which monopolize most of the railway transportation system in Canada carry also a sizeable portion of all goods transported by rail in the United States. Moreover, both companies exert a strong influence over Canadian maritime or air transportation.

In its opening brief before the Board of Conciliation under the Chairmanship of Judge J.C. Anderson, the company in 1956 asked among other things for the elimination of all agreements, rules, regulations or practices requiring the employment or use of firemen on other than steam power, and the establishment of a rule to provide that the company should have the unrestricted right to determine when and if a fireman shall be used on other than steam power. In such terms, the company laid out a request which brought about the first major strike on automation problems in the railroads.

Though the "locus dramatis" is in Canada, the Canadian onlooker is not a spectator to or a victim of a typically Canadian dispute. The conflict is North American, if not world-wide, by its origin and nature. Moreover, the dispute involves fundamentally more than the firemen. Due to recent technological advances in the field of electronics, railroad employers are likely to shift their combinations of manpower, and other categories of employees may find themselves in a state of periodic reshuffling. Some of them may even disappear, as is now foreseen.

The Canadian railway systems are part and parcel, economically speaking, of a well-integrated North American transportation unit. Though railroad operators compete among themselves for a larger share of the trade, they also face competition coming from road, air and maritime transportation systems. Various state or Federal boards determine transportation tariffs for all categories of carriers, which results in a certain rigidity in the sources of revenue. Over and beyond the fact that tariffs are frequently non competitive and hard to move, competition forces railroad operators to lower their operating costs, thus making it more difficult to raise wages or to keep certain categories of employees at their present employment. In such a context, any technological improvement which lowers costs, reduces manpower, increases productivity and permits better competition in terms of flexibility in the services is most certainly to be adopted by any large carrier. But in a competitive industry, any major improvement adopted by one competitor is certainly to be adopted by all who so devise to stay in the field. In other words, it becomes a question of life or death. The automated yard, the IBM machines, the diesel (without firemen) were the end product of technology plus the forces of competition. 
We are facing a continental dispute which begs for a continental solution. Though the cliché is repeated in many circles, the dispute is not among Canadians dominated by foreign interests. It is a dispute which by its very origin and nature knows only economic frontiers, and not political ones. We are involved in a family affair where we find close to one hundred and fifty employers, two of them being Canadian, who have engaged in a dispute with a Brotherhood which coexists with a large number of industrial or craft railway unions. All the disputants are vitally and critically interested in the outcome of any dispute brought about by technological or administrative changes. If things are not properly handled by both sides, May 11, 1958 may well appear in the future as the first round in a series of royal battles on both sides of the Canadian border.

In 1956, railways companies in the USA made an approach toward the elimination of the firemen working on diesel or non-steam traction. But the question was never brought to a board of conciliation. On the 21st of November 1956, all USA railroad companies signed a three-year contract with the Brotherhood, and till 1960 the USA firemen are not to be annoyed, for all practical purposes. The firemen question was thus shifted to the Canadian side of the border, in the hope that a Canadian settlement might trace the way to all operators in North America and eventually become the mode for future union-management relations in the North American Railway system. Meanwhile, the Canadian National Railways kept the USA model settlement and it remained for the CPR to experiment with new arrangements of operative personnel, to eliminate certain categories of firemen, and thus to pave the way to a new era in labor relations.

The experimental conditions were highly favorable for both sides of the continental dispute. Canada is a country larger than the USA and knows a wide variety of climatic, geographic and regional problems. The railroad systems share a virtual monopoly in the railway field, both systems linking two seas and much of the northern regions. Both systems go deep in the USA and are competitors to USA carriers. The Brotherhood rely on good settlements in USA and Canada as sound precedents for the diesel era, while the company could invoke the Canadian Anderson Report of December 19, 1956, which declared useless the employment of firemen on non-steam traction. The Brotherhood had just joined the Canadian Labour Congress and could count on the solid support of all railway unions. The issue was brought to a head in early January 1957.

The firemen strikes of January 1957 and May 1958 are merely two stages of a same work stoppage originating from a same and unique conflict between all USA and Canadian operators and the firemen. The first stage of the strike brought the whole CPR system to a complete halt and ended with the appointment of the Kellock Commission which found against the firemen. On May 11th, 1957, the second half of the strike began and ended on May 13th. A round is over, and the Kellock 
conclusions (thus are likely to say the Brotherhood leaders) are not to become the model for North America.

The history of the conflict and its real economic setting should be an occasion of deep reflection for our Government. It has displayed much effort and ingenuity to bring both sides to a common understanding. However, our Government has put itself in the role of mediator on the occasion of a conflict whose real dimensions encompass more than one country. We only have to remember the box-car problem to remind ourselves that to obtain durable settlements for continental problems, mediation must of necessity become a multi-State responsibility. Before long, governments directly affected by work stoppages in continent-wide economic units, such as that made up by our railroads, may have to come to terms over mediation formulas and machinery covering all countries directly affected.

The solid labor front of January 1957 has melted in May 1958. We have all been witness to an event seldom seen in the railways, and not likely to be repeated: railway employees crossing picket lines of other fellow-unionists on strike. And here we are faced with the complex problem created by a multitude of craft, multi-craft or quasiindustrial unions ignoring each other, though now in great need of each other. Efficiency for both parties may require a revamping of the railway unions and their merging into fewer and more awakened units. To increase its effectiveness, a union must know perfectly well the mechanisms of the labor market and must be ready to meet the employers at every point of the mechanisms where the welfare of the employee may be affected. The structure and the administration of the unions must therefore be adequate in order to meet the challenges. We have ourselves discussed the question at the 12th Industrial Relations Conference at Laval University in April 1957, and we refer the readers to the convention report. ${ }^{1}$

It appears clearly that railway unionism can no longer work on a craft or multi-craft basis, in an age of automation. May 13th, 1958, is the beginning of the end for inadequate union structures. We do not know, as yet, what is likely to happen to the firemen, as members of a distinct union. We foresee, however, that in the very near future, railway unionism shall have to be structured along industrial lines, or else every separate union shall be gobbled up one by one. And the last in the field shall be no stronger that those too weak to stay in the trade.

(1) Changements économiques et transformations syndicales. Quebec, 28 St. Famille St.: Les Presses Universitaires Laval, 1958. 184 pp. \$3.00. 